\title{
In Vitro Killing of Oral Capnocytophaga by Granule Fractions of Human Neutrophils Is Associated with Cathepsin G Activity
}

\author{
Kenneth T. Miyasaki and Amy L. Bodeau \\ Section of Oral Biology and Dental Research Institute, University of California, School of Dentistry, \\ Center for the Health Sciences, Los Angeles, California 90024
}

\begin{abstract}
The Capnocytophaga are inhabitants of the hypoxic human gingival crevice that are normally prevented by neutrophils from causing periodontal and systemic infection. To identify potential nonoxidative bactericidal mechanisms against Capnocytophaga within human neutrophils, gel filtration chromatography was used to fractionate neutrophil granule extracts. Seven granule fractions, designated A through G, were obtained. The Capnocytophaga were most sensitive to killing by fraction D. Fraction D exhibited substantial bactericidal activity under aerobic and anaerobic conditions. The bactericidal activity associated with ion-exchange subfractions D8-D11, which contained primarily cathepsin $G$ as assessed by enzymatic activity, amino acid composition, and $\mathrm{NH}_{2}$-terminal sequence. Heat-inactivation, diisopropylfluorophosphate, PMSF, and $\boldsymbol{N}$-benzyloxycarbonylglycylleucylphenylalanylchloromethyl ketone inhibited bactericidal activity against Capnocytophaga sputigena but not Escherichia coli. We conclude that $(a)$ human neutrophil cathepsin $G$ is an important antimicrobial system against the Capnocytophaga, (b) the bactericidal activity of cathepsin $\mathbf{G}$ against Capnocytophaga is oxygen independent, and $(c)$ an intact enzyme active site is involved in the killing of $C$. sputigena but not $E$. coli. We suggest that human neutrophil cathepsin $G$ is an important antimicrobial system against certain oral bacteria and that cathepsin $\mathbf{G}$ kills bacteria by two distinct mechanisms. (J. Clin. Invest. 1991. 87:1585-1593.) Key words: polymorphonuclear leukocyte $\bullet$ bactericidal $\bullet$ nonoxidative $\bullet$ chymotrypsin-like $\bullet$ cationic proteins
\end{abstract}

\section{Introduction}

The Capnocytophaga Spp. are gram-negative, capnophilic, facultative, gliding bacteria indigenous to dental plaque (1). In the oral cavity, Capnocytophaga have been associated with localized juvenile periodontitis, a rapid, destructive form of periodontal disease associated with intrinsic defects in neutrophil

This work was presented in part at the 68th General Session of the International Association for Dental Research, Cincinnati, OH, March 9-14, 1990, and was published in abstract form (J. Dent. Res. 69:Abstr. 1464).

Address correspondence to Dr. Kenneth Miyasaki, Section of Oral Biology, CHS 63-050, School of Dentistry, Center for the Health Sciences, University of California, Los Angeles, CA 90024-1668.

Received for publication 17 May 1990 and in revised form 2 November 1990.

J. Clin. Invest.

(c) The American Society for Clinical Investigation, Inc. 0021-9738/91/05/1585/09 \$2.00

Volume 87, May 1991, 1585-1593 chemotaxis (2). Conversely, oral infections by Capnocytophaga Spp. have apparently resulted in reversible, acquired systemic defects in neutrophil chemotaxis (3). In addition to their association with periodontal disease, Capnocytophaga are capable of producing systemic infection in man (4); and notably, in association with granulocytopenia $(5,6)$. Many blood isolates of $C a p$ nocytophaga are insensitive to serum bactericidal activity (7). Thus, it can be concluded that neutrophils must play an important role in controlling both periodontal and systemic infection by the genus Capnocytophaga.

The molecular aspects of phagocyte interactions with Capnocytophaga Spp. have yet to be described. Neutrophils are capable of killing Capnocytophaga in vitro (8). In general, neutrophils kill bacteria by both oxidative and nonoxidative mechanisms (9). The nonoxidative mechanisms include $(a)$ cationic peptides known as the defensins; $(b)$ the neutral serine protease family (NSP) ${ }^{1}$ including cathepsin G, elastase, azurocidin (possibly identical to CAP37), proteinase 3, and p29b (possibly identical to AGP7 and proteinase 3); (c) the bactericidal/permeability-increasing protein (B/PI); $(d)$ enzymes such as lysozyme; and $(e)$ cofactor-binding proteins including apolactoferrin, and possibly, cobalophilin (10-18). Many of these substances kill bacteria in a manner independent of enzymatic activity $(10,12,15-17,19)$. Cathepsin G, a chymotrypsin-like enzyme, has been reported to kill certain bacteria nonenzymatically $(15,20,21,22)$. As such, the function of the chymotryptic activity of cathepsin $G$ is unknown.

We examined the bactericidal activity of lysosomal constituents from human neutrophils against Capnocytophaga under aerobic and anaerobic conditions, and identified cathepsin $G$ as one of the primary oxygen-independent bactericidal mechanisms. Furthermore, we demonstrated that an active enzyme was required for the killing of Capnocytophaga by cathepsin G.

\section{Methods}

Bacteria and growth conditions. Capnocytophaga sputigena ATCC 33123, C. gingivalis ATCC 33124, C. ochracea ATCC 27872, and Escherichia coli ML-35 were grown overnight at $37^{\circ} \mathrm{C}$, in $5 \% \mathrm{CO}_{2} / 95 \%$ air on chocolate agar consisting of trypticase soy agar (BBL Microbiology Systems, Cockeysville, MD), $0.1 \%$ yeast extract (Difco Laboratories, Detroit, MI), 5\% heat-hemolyzed defibrinated horse blood (Mission Laboratories, Fontana, CA) $0.002 \%$ equine hemin III (Sigma Chemical Co., St. Louis, MO), $0.0001 \%$ menadione (Sigma Chemical Co.), and IsoVitale X supplement (BBL Microbiology Systems). E. coli ML-35

1. Abbreviations used in this paper: AU-PAGE, acid/urea polyacrylamide gel electrophoresis; DFP, diisopropylfluorophosphate; FPLC, medium pressure liquid chromatography; N-MSAAPVCK, $N$-methoxy-succinyl-alanylalanylprolylvalyl-chloromethyl ketone; NSP, neutral serine protease; TPCK, $N$ - $\alpha$-tosyl-phenylalanine-chloromethyl ketone; TSB, trypticase soy broth; Z-GLPCK, $N$-benzyloxycarbonyl-glycylleucyl --phenylalanyl-chloromethyl ketone. 
was a generously provided by Dr. R. I. Lehrer, UCLA School of Medicine. Bacteria were removed from plates and placed in trypticase soy broth containing $0.1 \%$ yeast extract, $0.002 \%$ equine hemin III, $0.0001 \%$ menadione, and $0.1 \%$ sodium bicarbonate (TSB), grown to mid log growth phase $\left(10^{9}\right.$ cells $\left./ \mathrm{ml}\right)$, adjusted to $10^{8}$ cells $/ \mathrm{ml}$ in TSB, and diluted $1: 100$ in a buffer consisting of $10 \mathrm{mM}$ sodium phosphate, $\mathrm{pH} 7.0$, producing a final $1 \% \mathrm{vol} / \mathrm{vol}$ concentration of TSB. In anaerobic studies, the organisms were grown for $24 \mathrm{~h}$ in an anaerobic chamber (Forma Scientific, Marietta, $\mathrm{OH}$ ) containing $85 \% \mathrm{~N}_{2}, 10 \% \mathrm{H}_{2}$, and $5 \%$ $\mathrm{CO}_{2}$; inoculated into anaerobically pre-equilibrated TSB, grown to mid log phase; and inoculated into anaerobically pre-equilibrated 10 $\mathrm{mM}$ sodium phosphate as described above. The bacterial cell concentration was determined turbidometrically (optical density at $540 \mathrm{~nm}$ of 0.1-0.3 was equivalent to $10^{9}$ cells $/ \mathrm{ml}$ ).

Preparation of PMN granules. Fresh human neutrophils were purified from granulocyte-enriched, leukocyte concentrates (Hemacare, Sherman Oaks, CA), using gelatin flotation, hypotonic lysis and Percoll sedimentation (23). Approximately $1.2 \times 10^{10} \mathrm{PMN}$ per leukocyte concentrate were obtained by these methods. Neutrophils were washed once in saline to remove Percoll then resuspended in an isotonic buffer consisting of $0.03 \mathrm{M}$ Tris- $\mathrm{HCl}, 0.01 \mathrm{M} \mathrm{NaCl}, 0.11 \mathrm{M} \mathrm{KCl}, 5 \mathrm{mM}$ $\mathrm{MgCl}_{2}$, and $7 \mathrm{mM}$ 2-mercaptoethanol, $\mathrm{pH}$ 7.5. This suspension was centrifuged, $300 \mathrm{~g}$ for $6 \mathrm{~min}$. The neutrophil pellet was resuspended in an hypotonic buffer consisting of $0.01 \mathrm{M}$ Tris- $\mathrm{HCl}, 8.4 \times 10^{-4} \mathrm{M} \mathrm{NaCl}$

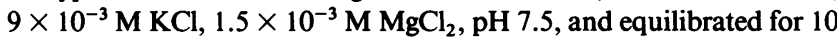
min. Granules were released from intact, swollen neutrophils by manual homogenization in a Potter-Elvejhem homogenizer. A hypertonic buffer, consisting of $0.046 \mathrm{M}$ Tris- $\mathrm{HCl}, 0.02 \mathrm{M} \mathrm{NaCl}, 0.22 \mathrm{M} \mathrm{KCl}, 8$ $\times 10^{-3} \mathrm{M} \mathrm{MgCl}_{2}$, and $0.014 \mathrm{M}$ 2-mercaptoethanol, $\mathrm{pH} 7.5$, was then added (1.1 part per 10 parts hypotonic buffer). This suspension was centrifuged at $300 \mathrm{~g}$ for $6 \mathrm{~min}$ to remove nucleii, ruptured and unruptured cells, and other debris. The turbid, granule-laden suspension was then chilled to $4^{\circ} \mathrm{C}$ and centrifuged at $32,000 \mathrm{~g}, 4^{\circ} \mathrm{C}$, for $20 \mathrm{~min}$. The dark green pellets were stored at $-85^{\circ} \mathrm{C}$ until needed.

Preparation of granule extracts and purified granule proteins. Granules were suspended in $0.5 \%$ cetyltrimethylammonium bromide, 0.02 M sodium acetate, $0.2 \mathrm{M} \mathrm{NaCl}, \mathrm{pH} 4.7$, and disrupted by homogenization in a Duall glass homogenizer at $4^{\circ} \mathrm{C}$. The suspension was centrifuged at $32,000 \mathrm{~g}$ for $20 \mathrm{~min}$ at $4^{\circ} \mathrm{C}$, and the clear green supernatant, containing $78.5 \mathrm{mg}$ protein, was collected and $60 \mathrm{mg}$ protein was loaded immediately on a Sephadex G-100 (Pharmacia-LKB Biotechnology, Piscataway, NJ) gel filtration column, $1.6 \times 100 \mathrm{~cm}$, equilibrated in $0.02 \mathrm{M}$ sodium acetate, $0.2 \mathrm{M} \mathrm{NaCl}, \mathrm{pH} 4.7$ (Buffer $\mathrm{A}$ ), $4^{\circ} \mathrm{C}$. The flow rate was $12 \mathrm{ml} / \mathrm{h}$, and 3-ml fractions were collected.

Medium pressure liquid chromatography (FPLC). Further isolation of microbicidal substances was achieved using medium pressure liquid chromatography (FPLC) by applying fraction D to a Mono-S HR 5/5 column (Pharmacia-LKB Biotechnology) equilibrated in Buffer A. Buffer B consisted of $0.02 \mathrm{M}$ sodium acetate, $2.0 \mathrm{M} \mathrm{NaCl}, \mathrm{pH} \mathrm{4.7}$, and was used to achieve a salt gradient. Final separation of proteins for amino acid analysis and $\mathrm{NH}_{2}$-terminal peptide sequence was achieved by reversed-phase FPLC using a ProRPC HR 5/2 column (PharmaciaLKB Biotechnology) equilibrated with $0.1 \%$ trifluoroacetic acid in water and a gradient formed by $0.1 \%$ trifluoroacetic acid in acetonitrile.

Microassays. Lysozyme (E.C. 3.2.1.77) was assayed by monitoring the decrease in optical density at $450 \mathrm{~nm}$ of a suspension of cell wall fragments of Micrococcus lysodeikticus in $0.1 \mathrm{M}$ phosphate buffer, $\mathrm{pH}$ 7.0 at $25^{\circ} \mathrm{C}(24)$. The lysozyme assay was performed using a kinetic microplate reader (Molecular Devices, Palo Alto, CA). Cathepsin G and elastase endpoint assays were also performed in microtiter format. In the elastase assay, samples were suspended in $0.1 \%$ Brij $35,0.05 \mathrm{M}$ Tris- $\mathrm{HCl}, 1.0 \mathrm{M} \mathrm{NaCl}$, and $0.1 \%$ trisodium EDTA, $\mathrm{pH}$ 8.5. The cathep$\sin \mathrm{G}$ assay was performed in $0.1 \%$ Brij $35,0.05 \mathrm{M}$ Tris- $\mathrm{HCl}$, and $0.1 \%$ trisodium EDTA, pH 7.5. The reaction was initiated by the addition of substrate $N$-benzyloxycarbonyl-L-alanyl-2-naphthyl ester, $50 \mu \mathrm{g} / \mathrm{ml}$, for elastase and $N$-benzoyl-D,L-phenylalanyl-2-naphthyl ester, $50 \mu \mathrm{g} /$ $\mathrm{ml}$, for cathepsin $\mathrm{G}(25)$. This mixture was incubated for $90 \mathrm{~min}$ at $37^{\circ} \mathrm{C}$, and terminated by the addition of soybean trypsin inhibitor at a final concentration of $300 \mu \mathrm{g} / \mathrm{ml}$. Released naphthal was detected by coupling to fast garnet, added at a final concentration of $40 \mu \mathrm{g} / \mathrm{ml}$. The sample was assayed spectrophotometrically at $520 \mathrm{~nm}$ using the microplate reader. Protein concentration was determined in microtiter format by the method of Bradford (26).

$S D S-P A G E$. SDS-PAGE was performed using the method of Laemmli (27) with a $12 \%$ resolving gel $(12 \% \mathrm{~T}, 2.6 \% \mathrm{C})$ and a $3 \%$ stacking gel $(3 \% \mathrm{~T}, 2.6 \% \mathrm{C})$ in a mini-gel system (Hoefer Scientific Instruments, San Francisco, CA). Electrophoresis was initiated by applying $53 \mathrm{~V}$ until the tracking dye formed a narrow band in the stacking gel, after which the voltage was increased and maintained at a constant $105 \mathrm{~V}$ (initially, $12.5 \mathrm{~mA} / \mathrm{gel}$ ). Gels were stained for protein using $0.125 \%$ Coomassie blue R-250 (Sigma Chemical Co.) in 50\% methanol: $10 \%$ acetic acid, and destained sequentially with $50 \%$ methanol: $10 \%$ acetic acid followed by $5 \%$ methanol: $7 \%$ acetic acid. The amount of sample added per was $5 \mu \mathrm{g}$ protein for Coomassie stain procedures and $2.5 \mu \mathrm{g}$ protein for blotting.

Acid-Urea Polyacrylamide Gel Electrophoresis ( $A U-P A G E)$. AUPAGE was performed in "tall" minigels (Hoefer Scientific Instruments) by a modification of the method of Panyim and Chalkley (28). Briefly, $12.5 \%$ acrylamide gels were modified to incorporate $3 \mathrm{M}$ urea and preelectrophoresed in $5 \%$ acetic acid at $150 \mathrm{~V}$ for $2 \mathrm{~h}$. Samples were dissolved in deionized $6 \mathrm{M}$ urea containing $7 \%$ acetic acid, and subsequent electrophoresis was performed at $200 \mathrm{~V}$ until the methylene green tracking dye eluted from the bottom of the gel. Gels were stained in $0.125 \%$ Coomassie Blue R-250 in $40 \%$ methanol, $15 \%$ formaldehyde, $5 \%$ acetic acid, and destained in $25 \%$ methanol, $3.7 \%$ formaldehyde as previously described (19).

Bactericidal assay. Bacteria were incubated with granule extract materials in a total volume of $40 \mu \mathrm{l}$ in $0.01 \mathrm{M}$ sodium phosphate, $\mathrm{pH}$ 7.0 , containing $1 \%$ vol/vol TSB, and maintained at $37^{\circ} \mathrm{C}$ (using a temperature block), unless otherwise indicated. When indicated, inhibitors were preincubated with the granule fractions for 10-120 min before admixture with bacteria. Additives used included PMSF(Sigma Chemical Co.), $N$ - $\alpha$-tosyl-phenylalanine-chloromethyl ketone (TPCK; Sigma Chemical Co.), $N$-benzyloxycarbonyl-glycylleucylphenylalanyl-chloromethyl ketone (Z-GLPCK; Enzyme System Products, Dublin, CA), methoxy-succinyl-alanylalanylprolylvalyl-chloromethyl ketone (NMSAAPVCK; Sigma Chemical Co.), $\alpha$-1-antitrypsin (Sigma Chemical Co.), and chymotrypsin A4 (Boehringer-Mannheim Biochemicals, Indianapolis, IN). TPCK is relatively unreactive against cathepsin $\mathrm{G}$, but Z-GLPCK and N-MSAAPVCK are highly specific inhibitors against cathepsin $\mathrm{G}$ and elastase, respectively (29). The bactericidal reaction was terminated by $1: 10$ dilution in $10 \mathrm{mM}$ sodium phosphate, $\mathrm{pH} 7.0$, and the resultant suspension was immediately spread on Laked blood agar plates using a Spiral plater (Spiral Systems, Bethesda, MD). Anaerobic assays were modified such that all reagents and cells were equilibrated anaerobically as described (30), under an atmosphere containing $85 \% \mathrm{~N}_{2}, 10 \% \mathrm{H}_{2}$, and $5 \% \mathrm{CO}_{2}$. After $48-72 \mathrm{~h}$ of incubation, CFU were enumerated. Bactericidal activity in dose-response assays was quantified as the $\log _{10}$ reduction in CFU, and calculated by the formula: $\delta\left[\log _{10}\right.$ killing] $=\log _{10} n_{\mathrm{o}}-\log _{10} n_{\mathrm{t}}$, where $\mathrm{n}$ is the bacterial $\mathrm{CFU} / \mathrm{ml}$ at time 0 or time t. The $n_{\mathrm{o}}$ was adjusted to $2-5 \times 10^{5} \mathrm{CFU} / \mathrm{ml}$ in all cidal assays. Variance of $\delta$ is described, where applicable, as a maximum estimate of the standard deviation, by the formula SD $\delta$ $=\log _{10} n_{\mathrm{t}}-\log _{10}\left(n_{\mathrm{t}}-\mathrm{SD}\right)$, where SD is the standard deviation of the $\mathrm{CFU} / \mathrm{ml}$.

Diisopropylfluorphosphate (DFP) inactivation. Purified human neutrophil cathepsin $G$ was also obtained from commercial sources (Biødesign International, Kennebunkport, ME). This cathepsin G was $>98 \%$ pure as assessed by SDS-PAGE (according to the vendor) and was virtually identical to subfractions D8-D1 1 by our own SDS-PAGE analysis. Serine protease activity of purified commercial cathepsin G, $500 \mu \mathrm{g}$, was inactivated with $20 \mathrm{mM}$ DFP (Sigma Chemical Co.), in 50 $\mathrm{mM}$ phosphate, $\mathrm{pH} 7.0,2 \mathrm{~h}$, on ice. DFP was eliminated by microdialysis against three exchanges of distilled water for $6 \mathrm{~h}$ at $4^{\circ} \mathrm{C}$.

Reversed-phase FPLC. Reversed-phase FPLC was performed using a ProRPC HR 5/2 (Pharmacia-LKB Biotechnology) column (C1-C4 
equivalent). Subfraction D8-D1 1 was applied using a $10 \mathrm{ml}$ superloop. The column was permitted to equilibrate in $0.1 \%$ trifluoroacetic acid. Elution was performed using a 20 -ml linear gradient from $0-40 \%$ acetonitrile containing $0.1 \%$ trifluoroacetic acid. Samples were concentrated by vacuum centrifugation using a SpeedVac (Savant Instruments, Farmingdale, NY).

Amino acid composition. The amino acid composition of $1-5 \mu \mathrm{g}$ of sample was analyzed with and without performic acid oxidation. The samples were hydrolyzed in $6 \mathrm{~N} \mathrm{HCl}$, deoxygenated, and incubated for $24 \mathrm{~h}$ at $100^{\circ} \mathrm{C}$. The samples were analyzed using an automated amino acid analyzer (Beckman Instruments, Fullerton, CA).

$\mathrm{NH}_{2}$-Terminal amino acid analysis. $\mathrm{NH}_{2}$-Terminal amino acid analysis was performed on $\sim 900$ pmol of ProRPC-purified protein by automated Edman degradation using a protein sequencer (model 475A; Applied Biosystems, Inc., Foster City, CA).

\section{Results}

Fractionation by gel filtration. Four peaks (two doublets) were pooled into seven fractions designated A-G (Fig. 1). Fraction B represented the valley $\mathrm{A}-\mathrm{B}$ region, and was collected separately since it has been reported to contain a cationic protein with bactericidal properties (16). The SDS-PAGE patterns of the higher molecular weight fractions, A-E, are shown in the inset. The major components of each fraction are identified in the figure legend where possible. The NSP were found in a broad zone with relative molecular masses between 22,000 and 30,000 . Identities of myeloperoxidase, lactoferrin, elastase, cathepsin G, lysozyme, and the defensins were confirmed by Western blot procedures (not shown). Fractions A-E were desalted by dialysis, $4^{\circ} \mathrm{C}$, against $0.005 \%$ acetic acid, and concentrated to dryness by lyophilization. Fractions $F$ and $G$ con-

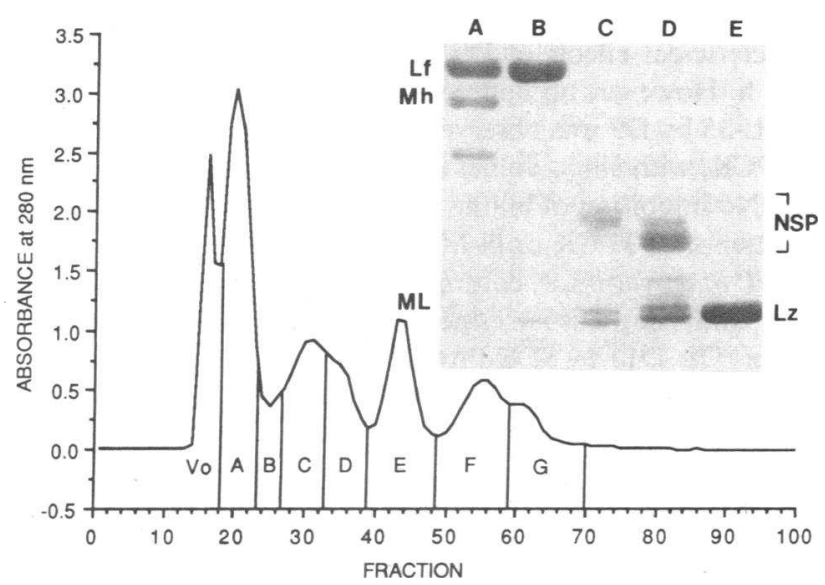

Figure 1. Chromatographic profile of a granule extract fractionated by gel filtration using Sephadex G-100. Total protein recovered in each fraction: $(V o) 3.2 \mathrm{mg},(A) 25.1 \mathrm{mg},(B) 7.2 \mathrm{mg},(C) 11.4 \mathrm{mg},(D) 10.0$ $\mathrm{mg},(E) 6.3 \mathrm{mg},(F) 2.3 \mathrm{mg},(G) 1.8 \mathrm{mg}$ (Bradford protein assay). The void volume, $V o$, was turbid, containing CETAB that had precipitated at $4^{\circ} \mathrm{C}$. SDS-PAGE of G-100 fractions $A-E, 12 \%$ gel, reducing conditions. $5 \mu \mathrm{g}$ protein was added to each lane. Fraction A contained lactoferrin (Lf) and myeloperoxidase heavy and light chains ( $M h$ and $M L$, respectively); fraction B contained lactoferrin; fractions $\mathrm{C}$ and D contained most of the NSPs; and fraction E contained relatively pure lysozyme $(L z)$. Coomassie-stainable components of fractions $\mathrm{F}$ and $G$ comigrated with the solvent front in this system and are not shown. tained the antimicrobial human neutrophil peptides, defensins, and were desalted by reversed-phase chromatography using a PepRPC HR 5/5 column (Pharmacia-LKB Biotechnology) and concentrated to dryness by lyophilization.

Susceptibility to the G-100 fractions under aerobic and anaerobic conditions. The Sephadex G-100 fractions were screened for bactericidal activity at $100 \mu \mathrm{g} / \mathrm{ml}$. Under aerobic conditions, fractions $\mathrm{C}$ and $\mathrm{D}$ were bactericidal against the three strains of Capnocytophaga and E. coli ML-35 (Table I). Fraction $\mathrm{B}$ exhibited variable cidal activity against $C$. sputigena and $C$. gingivalis. Fractions $F$ and $G$ exerted modest killing against $C$. ochracea, producing $>1 \log _{10}$ order of killing (i.e., $\left.\delta \log _{10}>1.0\right)$ under these assay conditions. Fraction D exhibited the most potent microbicidal activity, producing a $\delta \log _{10}$ $>3.0$ for each tested strain. Anaerobiosis decreased microbial susceptibility of all G-100 fractions. The only fraction with convincing microbicidal activity under anaerobiosis was fraction D, with $\delta \log _{10}$ between 2 and 3 against the Capnocytophaga at $100 \mu \mathrm{g} / \mathrm{ml}$. In terms of concentration dependency, the $\mathrm{D}$ fraction also exhibited more killing potency than the other fractions, showing $\delta \log _{10}$ of $1-2$ at $50 \mu \mathrm{g} / \mathrm{ml}$, and > 3 at 100 $\mu \mathrm{g} / \mathrm{ml}$ (Fig. 2).

Subfractionation of D using Mono-S. Mono-S cation-exchange chromatography was used to separate fraction $D$ into two main groups of protein-containing subfractions (designated "subfractions D1-D4" and "subfractions D8-D11," respectively), which were subdivided as shown in Fig. 3. On SDSPAGE, D8, D9, D10, and D11 exhibited one, main, diffuse or multiplet band which differed in relative molecular masses among each other, with a range between 24,000 and 28,000 (Fig. 3, inset). Subfraction D1 1 exhibited the lowest molecular mass, with a range between 22 and $23,000 M_{r}$; whereas subfraction D8 exhibited the highest, with a range between 24 and 28,000 $M_{\mathrm{r}}$. Subfractions D8-D11 all exhibited high arginine content, consistent with cathepsin G (Table II); however, subfraction D10 exhibited relatively higher levels of tyrosine than expected for cathepsin G. Subfractions D8-D11 eluted at 0.8 $\mathrm{M} \mathrm{NaCl}$ and hydrolyzed the chymotrypsin substrate $N$-benzoyl-D,L-phenylalanyl-2-naphthyl ester. These observations identified the major component of subfractions D8-D11 as cathepsin G. Subfraction D1 hydrolyzed Micrococcus leisodeikticus and represented lysozyme, a possible contamination from peak E. Peak D1 was not tested further in this study. Subfractions D2-D4 eluted at 0.3 to $0.4 \mathrm{M} \mathrm{NaCl}$, contained esterolytic activity for $N$-benzyloxycarbonyl-L-alanyl-2naphthyl ester, and represented the various isomers of elastase. The amino acid composition of subfraction D4 was consistent with elastase (Table II).

Susceptibility to Mono-S subfractions. The bactericidal activity of Mono-S subfractions against $C$. sputigena ATCC 33123 was tested in three different buffers: $10 \mathrm{mM}$ phosphate buffer, $10 \mathrm{mM}$ tris-140 mM saline, and $10 \mathrm{mM}$ phosphate-buffered $140 \mathrm{mM}$ saline, all at pH 7.0 (Fig. 4). The microbicidal activities of FPLC-purified subfractions D3, D4, D8-D11, were screened at $50 \mu \mathrm{g} / \mathrm{ml}$. Subfraction E1 was the only major peak obtained by Mono-S subfractionation of Sephadex G-100 fraction E. Subfraction E1 consisted of human neutrophil lysozyme and was included herein for comparison. Subfractions D9 and D10 were the most bactericidal, and the microbicidal activities of subfractions D3 and D4 were virtually negligible. Killing was inhibited in the presence of both normal saline and Tris. 
Table I. Killing of the Capnocytophaga Spp. by Sephadex G-100 Fractions A, B, C, D, E, F, and G under Aerobic and Anaerobic Conditions

\begin{tabular}{|c|c|c|c|c|c|c|c|c|}
\hline Organism & A & B & C & D & $\mathrm{E}$ & F & G & Control \\
\hline \multicolumn{9}{|l|}{ Aerobic } \\
\hline C. sputigena ATCC 33123 & 0.06 & 0.31 & 2.69 & 3.70 & 0.03 & 0.33 & 0.00 & 0.06 \\
\hline C. ginigivalis ATCC 33124 & 0.01 & 0.72 & 0.73 & $\cdot 3.39$ & 0.07 & 0.05 & 0.11 & 0.07 \\
\hline C. ochracea ATCC 27872 & 0.06 & 0.07 & 2.43 & 3.68 & 0.26 & 1.49 & 1.29 & 0.16 \\
\hline E. coli $\mathrm{ML}-35$ & $-0.50^{*}$ & -0.59 & -0.09 & 2.60 & -0.73 & $\mathrm{ND}^{\ddagger}$ & ND & -1.1 \\
\hline \multicolumn{9}{|l|}{ Anaerobic } \\
\hline C. sputigena ATCC 33123 & -0.08 & 0.02 & 0.48 & 3.17 & 0.04 & ND & ND & -0.00 \\
\hline C. gingivalis ATCC 33124 & -0.08 & 0.01 & -0.02 & 1.75 & -0.15 & ND & ND & -0.10 \\
\hline C. ochracea ATCC 27872 & 0.00 & 0.13 & 0.14 & 2.32 & 0.03 & ND & ND & 0.05 \\
\hline E. coli ML-35 & -0.93 & -0.46 & 0.60 & 2.39 & -0.93 & ND & ND & -0.89 \\
\hline
\end{tabular}

Control value is the solvent vehicle (water). All samples were adjusted to $100 \mu \mathrm{g}$ protein/ml by the Bradford method (26). Cidal assay performed for $2 \mathrm{~h}$ at $37^{\circ} \mathrm{C}$. Values are given as $\delta \log _{10}$ and represent the mean of quadruplicate assay. ${ }^{*}$ Negative value represents increase in CFU/ml.

${ }^{\ddagger}$ Not determined in this 2-h assay system.

Bactericidal activity of subfraction $D 9$ as a function of dose, time, ionic strength, and $\mathrm{pH}$. We next observed the effect of dose, time, ionic strength, and $\mathrm{pH}$ on killing by subfraction $\mathrm{D} 9$. The killing of $C$. sputigena ATCC 33123 by subfraction D9 followed exponential kinetics; however, a shoulder was suggested at $50 \mu \mathrm{g} / \mathrm{ml}$ (Fig. 5). A dramatic dose dependency was evident, and virtually no killing was observed at $20 \mu \mathrm{g} / \mathrm{ml}$. Both ionic conditions and $\mathrm{pH}$ influenced the bactericidal activity of subfraction D9 (Fig. 6). Killing was virtually abolished above $20 \mathrm{mM} \mathrm{NaCl}$. Alkaline pH enhanced the killing of $C$. sputigena ATCC 33123, but killing occurred throughout the $\mathrm{pH}$ range tested (pH 6.0-8.0).

Enzymatic activity and killing. We tested the effect of heat $\left(90^{\circ} \mathrm{C}, 10 \mathrm{~min}\right)$, PMSF, TPCK, Z-GLPCK, and $\mathrm{N}$ MSAAPVCK on the bactericidal activity of fraction D and subfraction D9 against $C$. sputigena ATCC 33123. Heating fraction $\mathrm{D}$ or subfraction $\mathrm{D} 9$ to $90^{\circ} \mathrm{C}$ for $10 \mathrm{~min}$ resulted in a 95.6-100\% reduction in enzymatic activity and a complete loss of bactericidal activity. The bactericidal activity of subfraction D9 could not be restored by the addition of $100 \mu \mathrm{g} / \mathrm{ml}$ chymotrypsin A4. When fraction D, $100 \mu \mathrm{g} / \mathrm{ml}$, and subfraction D9
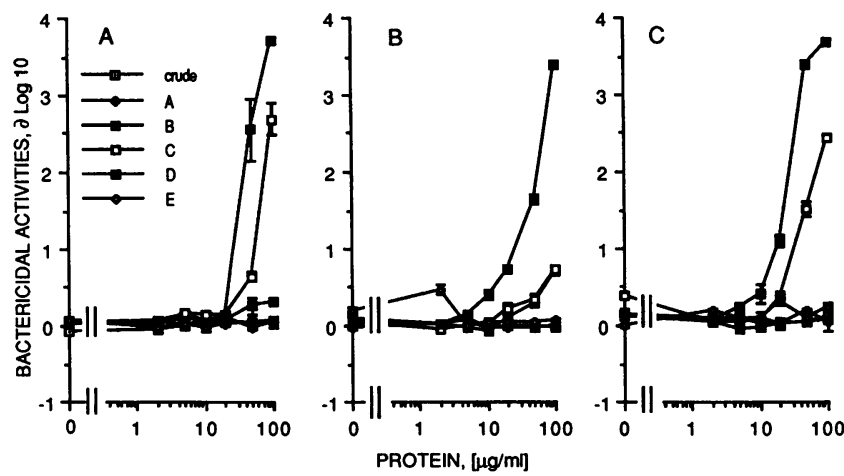

Figure 2. Sensitivity of the Capnocytophaga Spp. to killing granule fractions separated by the Sephadex G-100 gel filtration chromatography, under aerobic conditions. $(A)$ The killing of $C$. sputigena ATCC 33123; $(B)$ the killing of $C$. gingivalis ATCC 33124; and $(C)$ C. ochracea ATCC 27872 . Bactericidal activity is provided as $\delta \log _{10}$, as defined in Methods. Points and vertical bars represent the mean and SD $\delta$, respectively, of quadruplicate assays. were preincubated with PMSF for 10 min, cidal activity against C. sputigena ATCC 33123 was inhibited at PMSF concentrations above $10 \mu \mathrm{g} / \mathrm{ml}$ (Fig. 7). Inhibition of enzymatic activity by PMSF closely paralleled the inhibition of bactericidal activity. The specific inhibitor of cathepsin G, Z-GLPCK, partially reduced bactericidal activity (Table III). The elastase inhibitor, N-MSAAPVCK, also modestly depressed killing of fraction D but not subfraction D9, and its effect was much less than ZGLPCK. Chymotryptic esterolytic activity was inhibited by ZGLPCK but not N-MSAAPVCK. The inhibition of enzymatic activity by Z-GLPCK was $96 \pm 4 \%$, respectively. No inhibition of cidal activity was observed in the presence of TPCK. No inhibition of cidal activity was observed if cells were preincubated with $100 \mu \mathrm{g} / \mathrm{ml}$ PMSF for $2 \mathrm{~h}$, washed, and exposed to fraction D. In comparison, E. coli ML-35 was also sensitive to the bactericidal effects of D9, exhibiting a $\delta \log _{10}$ of $2.2 \pm 0.6$ over $2 \mathrm{~h}$. However, no appreciable inhibition of killing of $E$. coli ML-35 by D9 was observed in the presence of PMSF and Z-GLPCK, with $\delta \log _{10}$ values of $3.1 \pm 0.0$ and $2.9 \pm 0.0$, respectively. No inhibition of killing of $C$. sputigena was observed in the presence of TPCK or N-MSAAPV.

DFP inactivation. A commercially prepared, purified mixture of cathepsin $\mathrm{G}$ isoenzymes (essentially equivalent to subfractions D8-D11 by SDS-PAGE analysis) was exposed to the irreversible serine protease inhibitor, DFP. After enzyme inactivation, the DFP was eliminated by microdialysis. Between 96 and $101 \%$ inhibition of enzyme activity was estimated below $10 \mu \mathrm{g} / \mathrm{ml}$ (Fig. $8 A$ ). At $100 \mu \mathrm{g} / \mathrm{ml}$ DFP-inactivated cathepsin $\mathrm{G}, 86 \%$ inhibition was calculated, but was innacurate (too low) due to enzyme excess. Bactericidal activity against $C$. sputigena ATCC 33123 but not $E$. coli ML-35 was blocked by DFP inactivation (Fig. 8 B).

Reversed-phase isolation of cathepsin $G$ from subfractions D8-D11. Subfractions D8-D11 were pooled and reseparated using ProRPC reversed-phase FPLC (Fig. 9). Eight main component peaks were separated (I-VIII), but the majority of material $(>90 \%)$ that absorbed at $280 \mathrm{~nm}$ eluted as peak V. Peak V was collected and concentrated by vacuum centrifugation. The resultant peak fraction exhibited two closely spaced bands by acid/urea (AU)-PAGE (Fig. 9, inset). The amino acid composition of peak $\mathrm{V}$ revealed a relatively high proportion of arginyl residues (Table II). The amino acid composition of peak $\mathrm{V}$ 


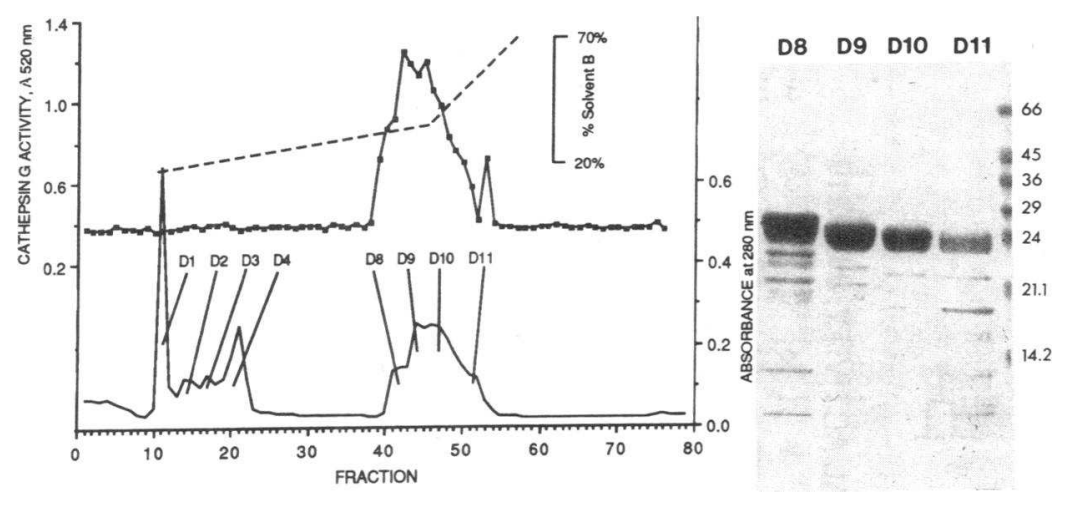

Figure 3. Cation-exchange chromatography on Mono-S of fraction D. 11 subfractions were collected. Labeled in the illustration are subfractions D1-D4 and D8-D11. Chymotrypsin-like esterolytic activity was associated with subfractions D8-D11, as shown in the enzyme activity profile. Subfraction D1 hydrolyzed $M$. leisodeikticus and represented lysozyme contamination from fraction E. Subfractions D2-D4 contained elastase-like esterolytic activity, and probably represent elastase, which was incompletely resolved by the overlap of fraction $\mathrm{C}$ and fraction $\mathrm{D}$. The $\mathrm{NaCl}$ gradient is shown by the broken lines. The subfractions D8-D11 exhibited diffuse banding on SDS-PAGE with $M_{r}$ between 22 and 28,000 (right panel). most closely resembles that of cathepsin $G$ as determined by others $(31,32)$. The amino-terminal analysis of peak $\mathrm{V}$ was: IIGGRESRPHSRPYMAYLQI, which is consistent with cathepsin $G$ (29). In comparison, the amino terminal sequence of the major component of subfraction D4 was: IVGGRRARPHA, which is consistent with elastase (31), but not cathep$\sin \mathrm{G}$, azurocidin, or p29b $(10,11,18,32)$.

Susceptibility to reversed-phase-purified cathepsin $G$. We tested the ability of Peak V to kill $C$. sputigena ATCC 33123. Peak V killed $C$. sputigena ATCC 33123, but produced $>3.5$ $\delta \log _{10}$ only at $500 \mu \mathrm{g} / \mathrm{ml}$, which represented a fivefold decrease in cidal potential compared to fraction $\mathrm{D}$ and subfraction $\mathrm{D} 9$. Additionally, enzymatic activity of peak $\mathrm{V}$ was not detectable at $1 \mu \mathrm{g} / \mathrm{ml}$.

\section{Discussion}

The net effect of the neutrophil is to protect the periodontium against periodontal infection (2). The specific mechanisms whereby the neutrophil affords such protection are unknown; however, certain clues indicate that nonoxidative antimicrobial systems are important to periodontal defense. First, individuals with specific granule deficiency and Chediak-Higashi syndrome exhibit severe periodontal infection (33). Second, neutrophils from such individuals are deficient in certain antimicrobial substances, including members of the defensin and neutral serine protease families (34). Third, although measurements of crevicular oxygen tension suggest that there is sufficient oxygen within the gingival crevice to support respiratory burst activity of neutrophils at about a $75 \%$ level $(35,36)$, many areas within the gingival crevice support the growth of obligate anaerobes (37); as such, oxidative killing may not be functional in crucial areas of periodontal defense.

In this study, the bactericidal activities of Sephadex G-100 gel filtration fractions prepared from neutrophil granule extracts against the Capnocytophaga were measured under both aerobic and anaerobic conditions, since paradoxically, nonoxi-

Table II. Amino Acid Composition of Subfractions D4, D8, D9, D10, D11, and Peak V and Comparison with Two Members of the NSP Family, Cathepsin G, and Elastase

\begin{tabular}{|c|c|c|c|c|c|c|c|c|}
\hline \multirow[b]{2}{*}{ Amino acid } & \multicolumn{8}{|c|}{ Residues* } \\
\hline & D4 & D8 & D9 & D10 & D11 & Peak V & Cathepsin G (32) & Elastase (31) \\
\hline Isoleucine & 11 & 11 & 11 & 12 & 10 & 13 & 14 & 12 \\
\hline Leucine & 18 & 14 & 14 & 14 & 12 & 17 & 20 & 25 \\
\hline Valine & 25 & 16 & 16 & 15 & 15 & 19 & 14 & 31 \\
\hline Threonine & 8 & 16 & 14 & 12 & 14 & 15 & 15 & 7 \\
\hline Alanine & 24 & 17 & 14 & 13 & 15 & 14 & 17 & 26 \\
\hline Glycine & 26 & 22 & 22 & 18 & 21 & 24 & 30 & 28 \\
\hline Histidine & 5 & 6 & 6 & 4 & 4 & 8 & 7 & 6 \\
\hline Phenylalanine & 8 & 5 & 6 & 5 & 4 & 6 & 9 & 11 \\
\hline Tyrosine & 2 & 4 & 6 & 16 & 5 & 7 & 7 & 3 \\
\hline Tryptophan & ND & ND & ND & ND & ND & ND & ND & ND \\
\hline Proline & 11 & 14 & 13 & 12 & 13 & 14 & 15 & 16 \\
\hline Cysteine & ND & ND & ND & ND & ND & 3 & 7 & 7 \\
\hline Serine & 20 & 20 & 17 & 14 & 18 & 19 & 19 & 13 \\
\hline Methionine & 2 & 2 & 3 & 3 & 2 & 4 & 5 & 4 \\
\hline Aspartate/asparagine & 23 & 19 & 18 & 18 & 17 & 21 & 23 & 24 \\
\hline Glutamate/glutamine & 20 & 26 & 23 & 22 & 23 & 26 & 26 & 18 \\
\hline Arginine & 22 & 34 & 35 & 30 & 30 & 44 & 38 & 24 \\
\hline Lysine & 1 & 3 & 4 & 4 & 3 & 4 & 5 & 0 \\
\hline
\end{tabular}

* Residues for D4, D8, D9, D10, D11, and peak V based upon an estimate of 225, 230, 220, 210, 205, and 255 residues per molecule, respectively. The number of residues of D8-D11 was assigned to be consistent with the $M_{r}$ as determined by SDS-PAGE. The number of residues of D4 and peak $V$ was assigned to facilitate comparison with published data for elastase (31) and cathepsin $G$ (32). 


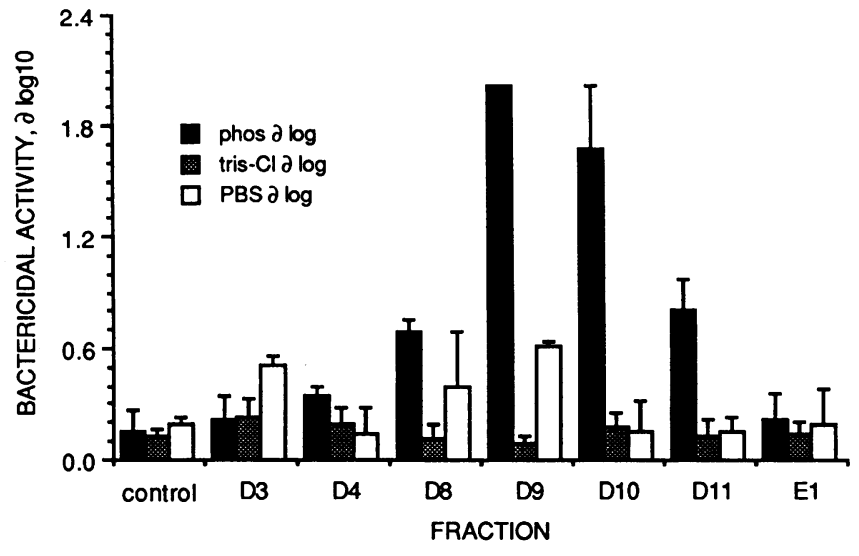

Figure 4. Testing subfractions D3, D4, D8, D9, D10, and D11 for bactericidal activity against $C$. sputigena ATCC 33123 in three buffer systems. Final concentration of each subfraction was adjusted to 50 $\mu \mathrm{g} / \mathrm{ml}$. Most bactericidal activity was associated with subfractions D9 and D10. Subfraction E1 represents lysozyme purified from fraction $\mathrm{E}$ by Mono-S FPLC, and is included for comparison. "Phos" indicates $10 \mathrm{mM}$ phosphate buffer, "tris- $\mathrm{Cl}$ " is $10 \mathrm{mM}$ tris containing 140 $\mathrm{mM} \mathrm{NaCl}$, and "PBS" indicates $10 \mathrm{mM}$ phosphate containing 140 $\mathrm{mM} \mathrm{NaCl}$. All solutions contained $1 \%$ TSB and were adjusted to $\mathrm{pH}$ 7.0. Columns and vertical bars represent the mean $\delta \log _{10}$ and $\operatorname{SD} \delta$, respectively, of quadruplicate assays.

dative killing mechanisms can require the presence of oxygen to kill microorganisms (38), presumably to support rapid microbial metabolism during the killing process. Fractions $A$ and E exerted no microbicidal activity against these organisms ei-

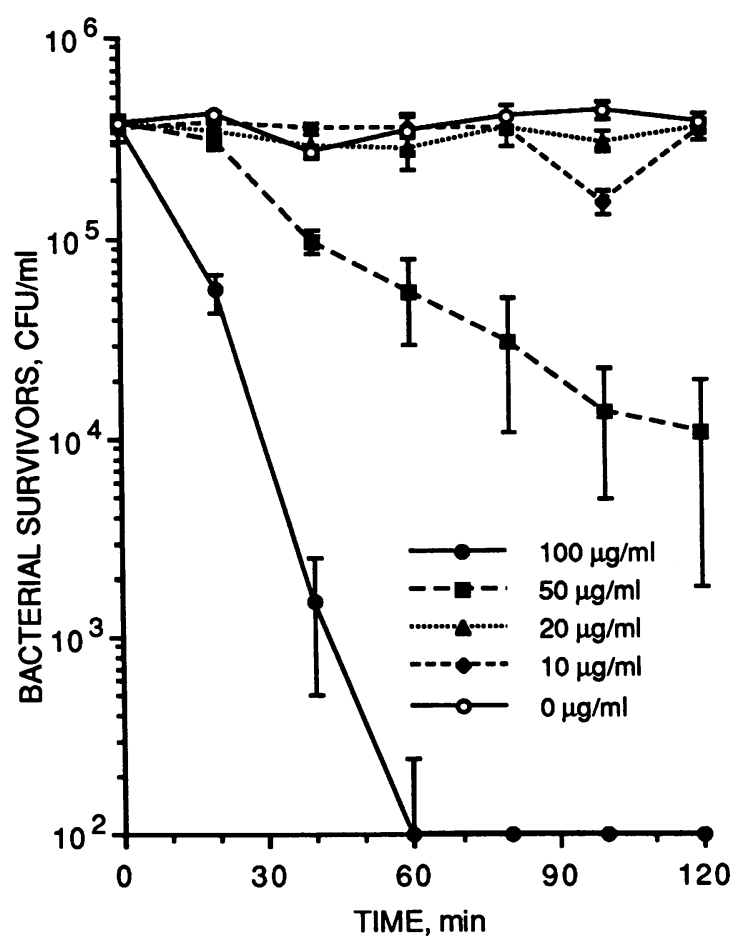

Figure 5. Kinetics of killing C. sputigena ATCC 33123 by subfraction D9. Assay was performed in $1 \%$ TSB and $10 \mathrm{mM}$ sodium phosphate, pH 7.0. Kinetics was examined at several concentrations: (๑) $100 \mu \mathrm{g} /$ $\mathrm{ml}$, (₫) $50 \mu \mathrm{g} / \mathrm{ml}$, ( $\Delta) 20 \mu \mathrm{g} / \mathrm{ml}$, (४) $10 \mu \mathrm{g} / \mathrm{ml}$, and (O) $0 \mu \mathrm{g} / \mathrm{ml}$ control. Points and vertical bars represent the mean $\delta \log _{10}$ and SD $\delta$, respectively, of quadruplicate assays.

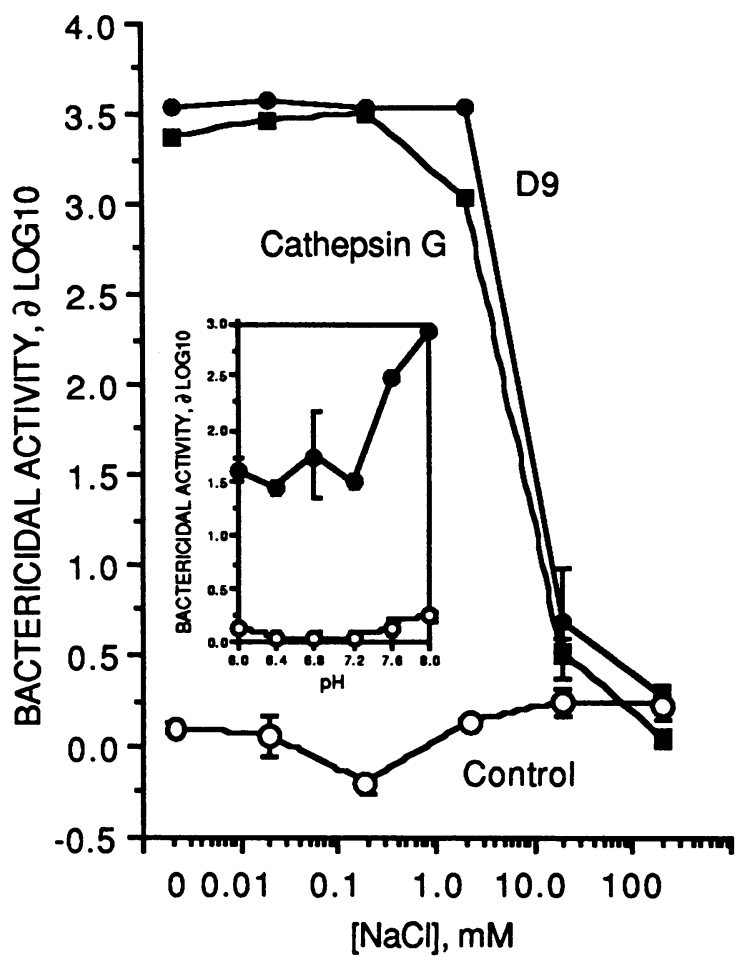

Figure 6. Effect of $\mathrm{NaCl}$ on the bactericidal activity of subfraction $\mathrm{D} 9$ $(\bullet)$ and commercially prepared cathepsin $\mathrm{G}(\boldsymbol{\bullet})$ against $C$. sputigena ATCC 33123 (large graph). Killing was observed below $20 \mathrm{mM} \mathrm{NaCl}$. Buffer controls are also shown (o). Subfraction D9 exhibited cidal activity throughout the tested pH range (inset). Buffer system was 10 $\mathrm{mM}$ sodium phosphate. Points and vertical bars represent the mean $\delta \log _{10}$ and SD $\delta$, respectively, of quadruplicate assays.

ther aerobically or anaerobically. Fractions C and D were microbicidal, but only fraction $\mathrm{D}$ was microbicidal under anaerobic conditions and at the concentrations tested. Thus, the components of fraction $\mathrm{D}$ may be important in killing oral bacteria within the hypoxic gingival crevice. Fractions $F$ and $G$, which were also microbicidal against the Capnocytophaga, yielded a number of peptides, including the defensins. Although neither $\mathrm{C}, \mathrm{D}, \mathrm{F}$, or $\mathrm{G}$ were pure, comparisons may be estimated based on assumed molecular weights of 30,000 (for C and D) and 3,000 (for $F$ and $G$ ). On a molar basis, the potency of $C$ and $D$ is $\sim 10$ times that of F and G. Similarly, we have observed that on a molar basis, the purified defensins, HNP-1, HNP-2, and HNP-3, are $\sim 10-20$ times less potent than cathepsin $G$ against certain oral bacteria in our assay conditions.

Fraction $\mathrm{D}$ consisted of a mixture of proteins as assessed by SDS-PAGE, but the majority of these exhibited an $M_{r}$ between 22 and 28,000. Fraction D contained virtually all chymotrypsin-like and some elastase-like esterase activity. Bactericidal activity of fraction $D$ segregated with the extremely cationic protein subfractions (subfractions D8-D11) that eluted at or above $0.7 \mathrm{M} \mathrm{NaCl}$ from Mono-S. The chromatographic profile of chymotryptic activity closely resembled the profile of absorbance at $280 \mathrm{~nm}$. Because our subfractions D8-D1 1 resembled commercially prepared cathepsin G by SDS-PAGE, we attribute the irregular shape of the D8-D11 peak to the presence of carbohydrate-based isomeric forms of cathepsin $G(39,40)$ rather than proteolytic fragmentation. Subfractions D8-D11 exhibited amino acid compositions consistent with cathepsin 

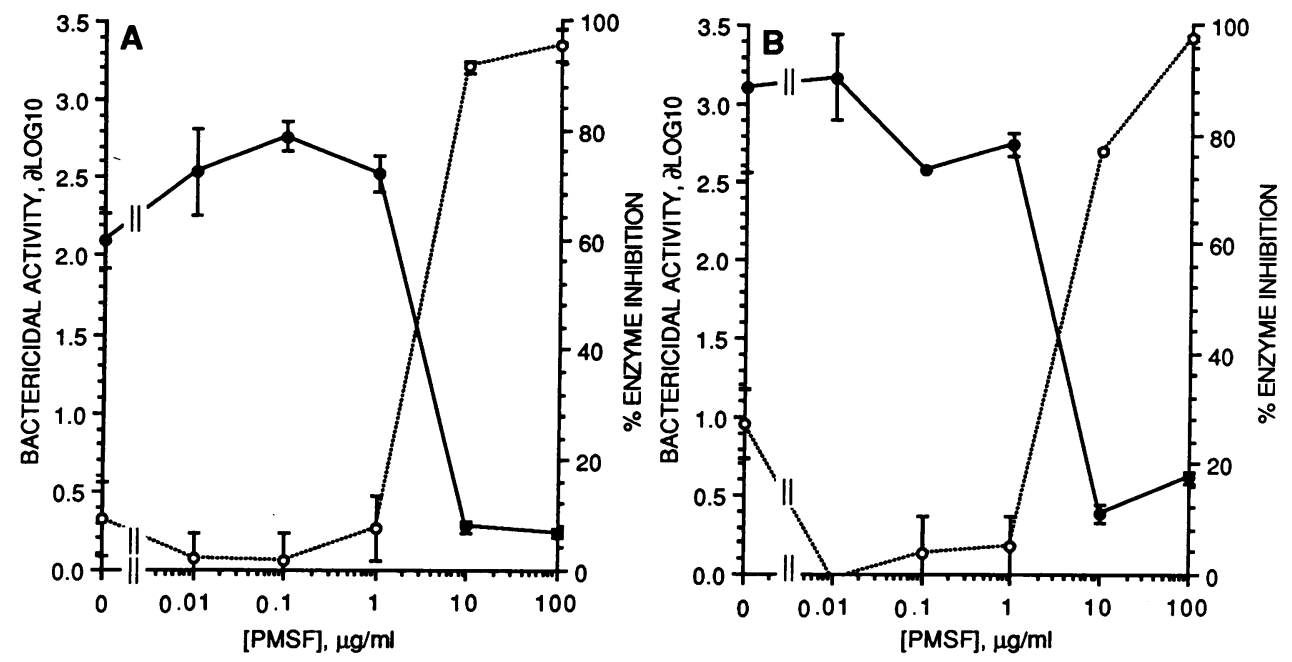

Figure 7. The inhibitory effect of PMSF on the bactericidal activity of fraction $\mathrm{D}(A)$ and subfraction $\mathrm{D} 9$ $(B)$. Bactericidal activity $(\bullet)$ is provided as $\delta \log _{10}$, as defined in Methods. Enzyme assay data (o) is provided as percent of uninhibited enzymatic activity. Points and vertical bars represent the mean $\delta \log _{10}$ and $\mathrm{SD} \delta$, respectively, of quadruplicate assays.
G; however, subfraction D10 revealed higher levels of tyrosine residues than expected and in comparison to the other subfractions. No detectable microbicidal activity was associated with the elastase-containing subfractions (subfractions D3 and D4).

Cathepsin $\mathrm{G}$ is a relatively poor proteinase and little is known about the true function of this enzyme (40). Lehrer et al. (41) demonstrated that chymotrypsin-like cationic proteins killed fungi in a manner that was independent of enzymatic

Table III. Inhibition of Killing of C. sputigena ATCC 33123 by the Specific Enzyme Inhibitors of Cathepsin $G$ and Elastase, Z-GLPCK, and N-MSAAPVCK, Respectively, and by the Unreactive Chloromethyl Ketone TPCK

\begin{tabular}{lr}
\hline \multicolumn{1}{c}{ Reagents } & $\begin{array}{r}\text { Bactericidal } \\
\text { activity }^{*} \\
\left(\delta \log _{10} \pm \text { sd } \delta\right)\end{array}$ \\
\hline Fraction D + solvent DMSO ${ }^{\ddagger}$ & $\delta \log _{10} \pm S D \delta$ \\
Fraction D + Z-GLPCK' & $3.46 \pm 0.00$ \\
Fraction D + N-MSAAPVCK & $0.67 \pm 0.04$ \\
Fraction D + Z-GLPCK + N-MSAAPVCK & $1.26 \pm 0.06$ \\
Fraction D + TPCK & $0.00 \pm 0.02$ \\
Solvent DMSO & $3.46 \pm 0.00$ \\
Z-GLPCK & $0.07 \pm 0.05$ \\
N-MSAAPVCK & $0.04 \pm 0.02$ \\
Z-GLPCK + N-MSAAPVCK & $-0.06 \pm 0.06$ \\
Subfraction D9 & $0.11 \pm 0.03$ \\
Subfraction D9 + Z-GLPCK & $2.56 \pm 0.00$ \\
Subfraction D9 + N-MSAAVPCK & $0.59 \pm 0.15$ \\
Subfraction D9 + Z-GLPCK + N-MSAAVPCK & $2.45 \pm 0.82$ \\
Subfraction D9 + solvent DMSO & $0.81 \pm 0.03$ \\
Subfraction D9 + TPCK & $3.05 \pm 0.10$ \\
\hline
\end{tabular}

* Bactericidal assays of fraction D and subfraction D9, $100 \mu \mathrm{g} / \mathrm{ml}$, were performed for $2 \mathrm{~h}$ at $37^{\circ} \mathrm{C}$. Values are given as $\delta \log _{10}$ and represent the mean and SD $\delta$ of triplicate assay.

₹ DMSO was used to solubilize the inhibitors Z-GLPCK, N-

MSAAPVCK, and TPCK, and was present in the bactericidal assay at concentrations up to $0.005 \% \mathrm{vol} / \mathrm{vol}$. Control DMSO was provided in the assay at $0.005 \% \mathrm{vol} / \mathrm{vol}$.

'Inhibitors or DMSO were preincubated with fraction D and subfraction $\mathrm{D} 9$ for $2 \mathrm{~h}$ at $24^{\circ} \mathrm{C}$. Inhibitor concentrations were $5 \mu \mathrm{g} / \mathrm{ml}$. activity. Subsequently, other investigators have noted that enzyme activity was not essential in the killing of organisms such as Escherichia coli, Acinetobacter, staphylococci, and gonococci (15, 20-22). Recently, azurocidin, a member of the NSP family that lacks enzymatic activity has been discovered (11). Azurocidin exhibits potent microbicidal activity against nonoral bacteria (10), suggesting that enzymatic activity is not a necessary requirement for killing of bacteria by certain members of the NSP family.

In this study, we found that enzymatic activity of crude (fraction D), relatively pure (subfraction D9), and commercially purified cathepsin $\mathrm{G}$ was associated with microbicidal activity against the oral Capnocytophaga, but not the control organism, $E$. coli. Persuasively, PMSF-inactivated or DFP-inactivated cathepsin $\mathrm{G}$ killed $E$. coli but not $C$. sputigena. The microbicidal activities of fraction D and subfraction D9 against C. sputigena ATCC 33123 were diminished by heat inactivation, PMSF, and the cathepsin G-specific inhibitor Z-GLPCK. No inhibition of cidal activity was observed in the presence of the solvent vehicle DMSO, or the control chloromethyl ketone TPCK. Some inhibition of the bactericidal activity of fraction D, but not subfraction D9, was also observed with $\mathrm{N}$ MSAAPVCK, the elastase-specific inhibitor. The simplest interpretation of this observation is that the bactericidal activity of fraction $\mathrm{D}$ against $C$. sputigena resulted from a synergistic interaction of both elastase and cathepsin G. Furthermore, the bactericidal activity of elastase was dependent upon cathepsin $G$, since elastase-containing fractions alone (D3 and D4) exerted no cidal activity. Regardless of the exact interactional properties of cathepsin $G$ and elastase, these results demonstrate that cathepsin $\mathrm{G}$ is bactericidal against $C$. sputigena and that either enzymatic activity and/or an intact enzyme active site is required for killing of $C$. sputigena.

The reason that the killing of $C$. sputigena required an intact enzyme active site is unknown. Although this may reflect a requirement for enzymatic activity, it may also reflect the participation of the enzyme active site in the binding of cathepsin $\mathrm{G}$ to the surface of $C$. sputigena. In either case, this is a unique observation. However, there are some clues as to the potential determinant interactions between $C$. sputigena and cathepsin $G$ that remain to be investigated. It has been reported that certain outer membrane proteins of gonococci are susceptible to hydrolysis by cathepsin G (42), and that the LPS may mask 

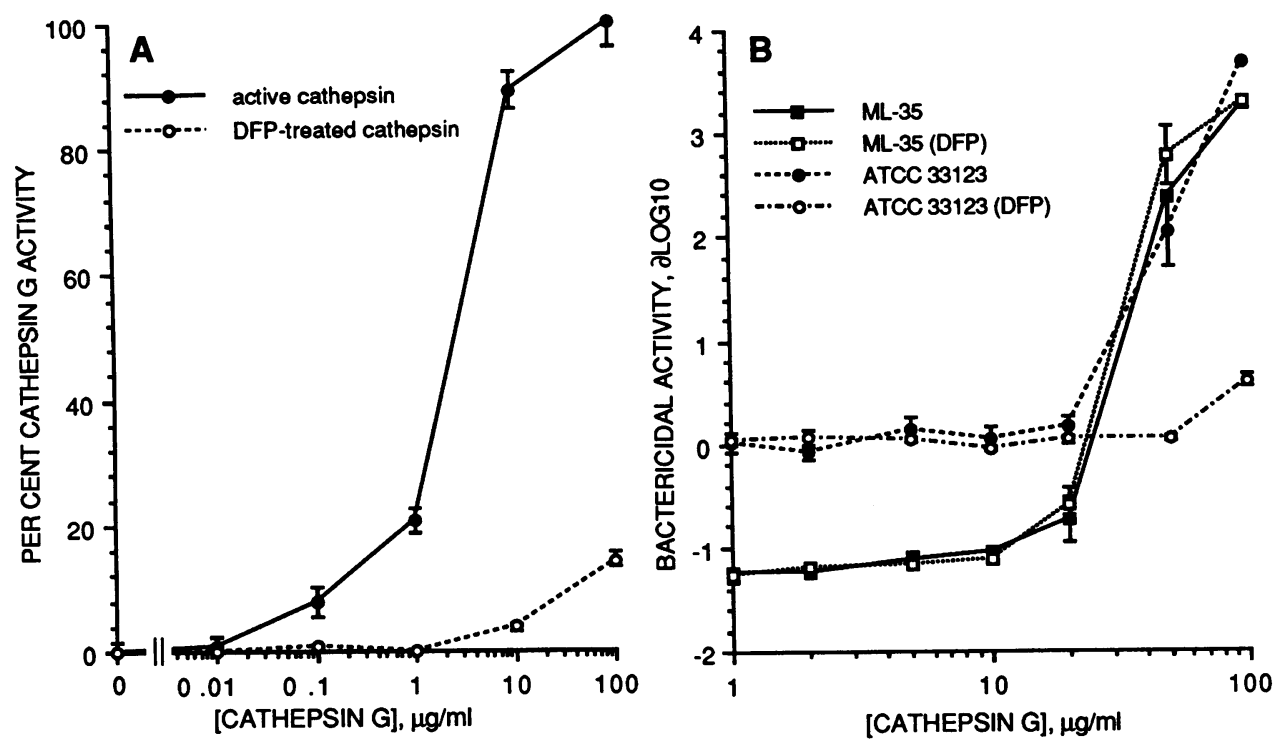

Figure 8. DFP inactivation of enzyme activity $(A)$ and killing of $C$. sputigena ATCC 33123 and E. coli ML-35 $(B)$ by commercially prepared cathepsin G. Enzyme activities are expressed in terms of percent of activity of cathepsin $\mathrm{G}$ at 100 $\mu \mathrm{g} / \mathrm{ml}$ (enzyme excess) as a function of the concentration of cathepsin G or DFP-inactivated cathepsin G. Points and vertical lines represent the means and standard deviation of triplicate assay. Killing of $C$. sputigena ATCC 33123 and E. coli ML-35 is shown as a function of cathepsin $\mathbf{G}$ concentration and DFP-inactivated cathepsin G concentration. Points and vertical bars represent the mean $\delta \log _{10}$ and SD $\delta$, respectively, of quadruplicate assays. potential target outer membrane proteins (21). As such, it is possible that unlike previously tested organisms, $C$. sputigena both possesses LPS that does not confer such masking and also exposes susceptible proteins that must be enzymatically damaged for killing to occur.

No inhibition of killing was observed when $C$. sputigena ATCC 33123 was pretreated with the irreversible serine protease inhibitor PMSF, washed, and exposed to fraction D. We

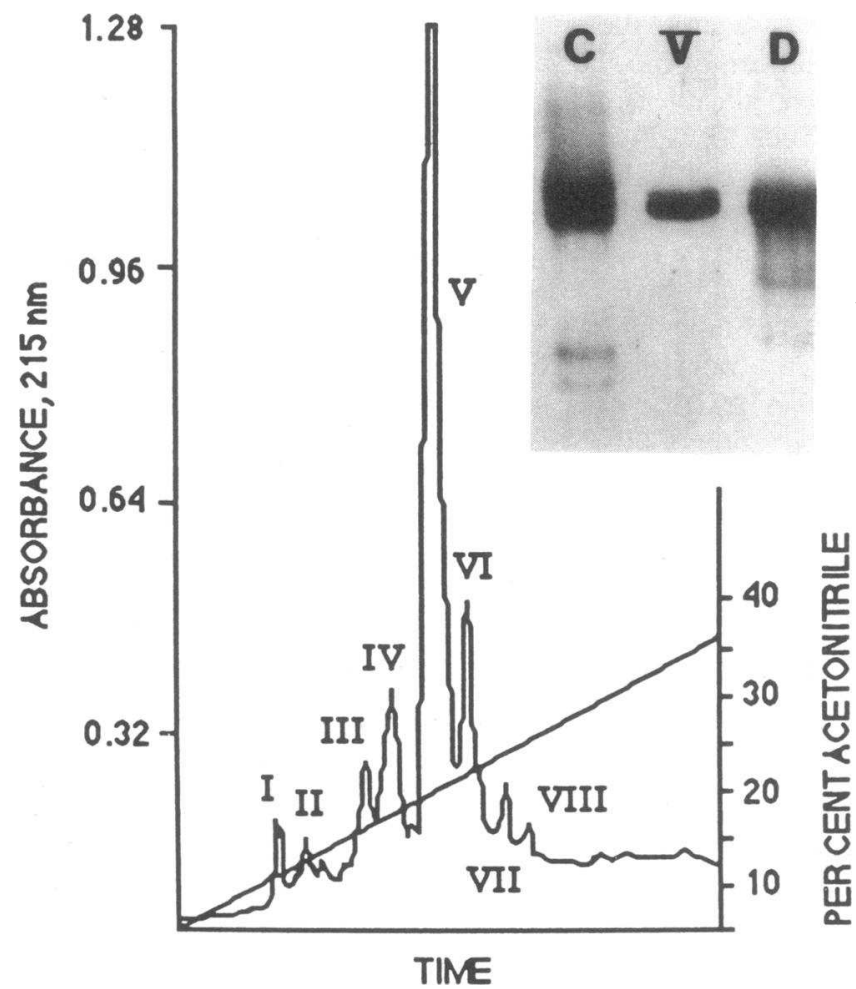

Figure 9. Reversed-phase FPLC on a ProRPC HR 5/2 column. Flow rate was $0.5 \mathrm{ml} / \mathrm{min}$. Absorbance profile at $215 \mathrm{~nm}$ is shown, AUFS $=1.28$. Eight major peak fractions were observed. Peak $\mathrm{V}$ was the predominant peak. By AU-PAGE, peak V revealed two bands (inset), and is shown in comparison to fractions $C$ and $D$. surmise that endogenous bacterial proteases were not involved in the cidal effects of fraction D. Also, chymotrypsin A4 could not restore the cidal effects of heat-inactivated subfraction D9. As such, chymotryptic activity alone was not sufficient to kill C. sputigena. Also, it seems more likely that the cationic properties of cathepsin $G$ enabled the enzyme to exert lethal effects, and not that the enzyme prepared the bacterial surface for the lethal effects of a cationic molecule.

We found that pooled subfractions D8-D1 1 compared well in terms of purity with commercially prepared human cathep$\sin \mathrm{G}$ (> 98\% pure) as assessed by SDS-PAGE. Reversed-phase chromatography FPLC using a ProRPC HR 5/2 column (a C1-C4 equivalent) verified that the major component of subfractions D8-D11 was cathepsin G. The major peak separated from the subfractions D8-D1 1 by reversed-phase chromatography was designated peak V. Peak V represented $>90 \%$ of the total material in subfractions D8-D1 1, and produced a doublet banding pattern on AU-PAGE. The high number of arginyl residues, the presence of lysinyl groups, and the $\mathrm{NH}_{2}$-terminal amino acid sequence were consistent with cathepsin G. Peak V represented a more highly purified cathepsin $G$ than subfractions D8-D11, yet was about five times less potent against $C$. sputigena than either fraction D or subfractions D8-D11, and exerted no microbicidal activity at $50-100 \mu \mathrm{g} / \mathrm{ml}$. We believe this resulted from the enzymatic inactivation of peak $\mathrm{V}$ by the organic solvent and the ion-pairing agent used in the reversedphase separation, acetonitrile, and trifluoroacetic acid (43). The cidal activity observed at higher concentrations $(500 \mu \mathrm{g} /$ $\mathrm{ml}$ ) may be ascribable to either nonenzymatic, cationic interactions alone, contaminating azurocidin, or to trace residual enzymatic activity. The first explanation suggests that $C$. sputigena may be sensitive to two modes of killing by cathepsin G; however, other experimental approaches will be required to resolve these issues.

In summary, oral bacteria of the genus Capnocytophaga were killed in an oxygen-independent fashion by nonoxidative microbicidal systems of human neutrophils, including cathep$\sin$ G, a member of the NSP family. Additionally, enzymatic activity was closely associated with the killing of Capnocytophaga by cathepsin $\mathrm{G}$ at lower concentrations. This observation suggests that an intact enzyme active site and possibly, 
enzymatic activity itself, is involved in the killing of $C$. sputigena by cathepsin $\mathrm{G}$. We propose that this enzyme-dependent killing of a microorganism by a neutral serine protease represents a heretofore undescribed process and suggest that one of the functions of the chymotryptic activity of cathepsin $G$ is the killing of certain bacteria. Additional research will be required to elucidate the mechanisms of this "enzymatic killing."

\section{Acknowledgments}

We thank Dr. Robert I. Lehrer for his critical appraisal of this work. We gratefully acknowledge Dr. Audree V. Fowler and the UCLA Protein Microsequencing Laboratory for the amino acid analysis and the $\mathrm{NH}_{2}$-terminal amino acid sequence determination.

This work was supported in part by U.S. Public Health Service grant DE-08161 from the National Institutes of Health, National Institute of Dental Research (NIH-NIDR). K. T. Miyasaki is a recipient of Research Career Development Award DE 00282 from NIH-NIDR.

\section{References}

1. Newman, M. G., and S. S. Socransky. 1977. Predominant cultivable microbiota in periodontosis. J. Periodontal Res. 12:120-128.

2. Van Dyke, T. E., C. Wilson-Burrows, S. Offenbacher, and P. Henson. 1987. Association of an abnormality of neutrophil chemotaxis in human periodontal disease with a cell surface protein. Infect. Immun. 55:2262-2267.

3. Shurin, S. B., S. S. Socransky, E. Sweeney, and T. P. Stossal. 1979. A neutrophil disorder induced by Capnocytophaga, a dental microorganism. $N$. Engl. J. Med. 301:849-854.

4. Gilligan, P. H., L. R. McCarthy, and B. K. Bissett. 1981. Capnocytophaga ochracea septicemia. J. Clin. Microbiol. 13:643-645.

5. Forlenza, S. W., M. G. Newman, A. I. Lipsey, S. E. Seigel, and U. Blachman. 1980. Capnocytophaga sepsis: a newly recognized clinical entity in granulocytopenic patients. Lancet. i:567-568.

6. Gandola, C., T. Butler, S. Badger, E. Cheng, and S. Beard. 1980. Septicemia caused by Capnocytophaga in a granulocytopenic patient with glossitis. Arch. Intern. Med. 140:851-852.

7. Wilson, M. E., J. T. Jonak-Urbanczyk, P. M. Bronson, K. C. Dudas, M. A. Apicella, and R. J. Genco. 1987. Capnocytophaga species: increased resistance of clinical isolates to serum bactericidal reaction. J. Infect. Dis. 156:99-106.

8. Baker, P. J., and M. E. Wilson. 1988. Effect of clindamycin on neutrophil killing of Gram-negative periodontal bacteria. Antimicrob. Agents Chemother. 32:1521-1527.

9. Ganz, T., M. E. Selsted, and R. I. Lehrer. 1986. Antimicrobial activity of phagocyte granule proteins. Semin. Respir. Infect. 1:107-117.

10. Campanelli, D., P. A. Detmers, C. F. Nathan, and J. E. Gabay. 1990 Azurocidin and a homologous serine protease from neutrophils. Differential antimicrobial and proteolytic properties. J. Clin. Invest. 85:904-915.

11. Gabay, J. E., R. W. Scott, D. Campanelli, J. Griffith, C. Wilde, M. N. Marra, M. Seeger, and C. F. Nathan. 1989. Antibiotic proteins of human polymorphonuclear leukocytes. Proc. Natl. Acad. Sci. USA. 86:5610-5614.

12. Hovde, C. J., and B. H. Gray. 1986. Characterization of a protein from normal human polymorphonuclear leukocytes with bactericidal activity agains Pseudomonas aeruginosa. Infect. Immun. 54:142-148.

13. Iacono, V. J., P. R. Boldt, B. J. MacKay, M.-I. Cho, and J. J. Pollock 1983. Lytic sensitivity of Actinobacillus actinomycetemcomitans Y4 to lysozyme. Infect. Immun. 40:773-784.

14. Kalmar, J. R. and R. R. Arnold. 1988. Killing of Actinobacillus actinomycetemcomitans by human lactoferrin. Infect. Immun. 56:2552-2557.

15. Odeberg, H., and I. Olsson. 1975. Antibacterial activity of cationic proteins of human granulocytes. Infect. Immun. 25:597-602.

16. Shafer, W. M., L. E. Martin, and J. K. Spitznagel. 1984. Cationic antimicrobial proteins isolated from human neutrophil granulocytes in the presence of diisopropyl fluorophosphate. Infect. Immun. 45:29-35.

17. Weiss, J., P. E. Elsbach, I. Olsson, and H. Odeberg. 1978. Purification and characterization of a potent bactericidal and membrane active protein from the granules of human polymorphonuclear leukocytes. J. Biol. Chem. 253:26642672.

18. Wilde, C. G., J. L. Snable, J. E. Griffith, and R. W. Scott. 1990. Character- ization of two azurophil granule proteases with active site homology to neutrophil elastase. J. Biol. Chem. 265:2038-2041.

19. Ganz, T., M. E. Selsted, D. Szklarek, S. S. L. Harwig, K. Daher, D. F. Bainton, and R. I. Lehrer. 1985. Defensins. Natural peptide antibiotics of human neutrophils. J. Clin. Invest. 76:1427-1435.

20. Thorne, K. J. I., R. C. Oliver, and A. J. Barrett. 1976. Lysis and killing of bacteria by lysosomal proteinases. Infect. Immun. 14:555-563.

21. Shafer, W. M. 1988. Lipopolysaccharide masking of gonococcal outermembrane proteins modulates binding of bacterial cathepsin $\mathrm{G}$ to gonococci. $J$. Gen. Microbiol. 134:539-545.

22. Shafer, W. M., and V. C. Onunka. 1989. Mechanism of staphylococcal resistance to non-oxidative antimicrobial action of neutrophils: importance of $\mathrm{pH}$ and ionic strength in determining the bactericidal action of cathepsin $\mathrm{G}$. $J$. Gen. Microbiol. 135:825-830.

23. Miyasaki, K. T., M. E. Wilson, E. Cohen, P. C. Jones, and R. J. Genco. 1986. Evidence for and partial characterization of three major and three minor chromatographic forms of human neutrophil myeloperoxidase. Arch. Biochem. Biophys. 246:751-764.

24. Decker, L. A. 1977. Worthington Enzyme Manual. Worthington Biochemical Corp., Freehold, NJ. 185-188.

25. Starkey, P. M., and A. J. Barrett. 1976. Neutral proteinases of human spleen. Purification and criteria for homogeneity of elastase and cathepsin G. Biochem. J. 155:255-263.

26. Bradford, M. M. 1976. A rapid and sensitive method for the quantitation of microgram quantities of protein utilizing the principle of protein dye-binding. Anal. Biochem. 7:248-254.

27. Laemmli, U. K. 1970. Cleavage of structural proteins during the assembly of the head of bacteriophage T4. Nature (Lond.). 277:680-685.

28. Panyim, S., and R. Chalkley. 1969. High resolution acrylamide gel electrophoresis of histones. Arch. Biochem. Biophys. 130:337-346.

29. Powers, J. C., B. F. Gupton, M. O. Lively, N. Nishino, and R. J. Whitley. 1978. Synthetic inhibitors of granulocyte elastase and cathepsin G. In Neutral Proteases of Human Polymorphonuclear Leukocytes. K. Havemann and A. Janoff, editors. Urban \& Schwarzenberg, Baltimore. 221-233.

30. Miyasaki, K. T., M. E. Wilson, A. J. Brunetti, and R. J. Genco. 1986. Oxidative and nonoxidative killing of Actinobacillus actinomycetemcomitans by human neutrophils. Infect. Immun. 53:154-160.

31. Heck, L. W., W. L. Darby, F. A. Hunter, A. Bhown, E. J. Miller, and J. C. Bennett. 1985. Isolation, characterization, and amino-terminal amino acid sequence analysis of human neutrophil elastase from normal donors. Anal. Biochem. 149:153-162.

32. Heck, L. W., K. S. Rostand, F. A. Hunter, and A. Bhown. 1986. Isolation, characterization, and amino-terminal amino acid sequence analysis of human neutrophil cathepsin G from normal donors. Anal. Biochem. 158:217-277.

33. Charon, J. A., S. E. Mergenhagen, and J. I. Gallin. 1985. Gingivitis and oral ulceration in patients with neutrophil dysfunction. J. Oral Pathol. 14:150 155.

34. Ganz, T., J. A. Metcalf, J. I. Gallin, and R. I. Lehrer. 1988. Microbicidal/ cytotoxic proteins of neutrophils are deficient in two disorders: Chediak-Higashi syndrome and "specific granule deficiency." J. Clin. Invest. 82:552-556.

35. Gabig, T. G., S. I. Bearman, and B. M. Babior. 1979. Effect of oxygen tension and $\mathrm{pH}$ on the respiratory burst of human neutrophils. Blood. 53:11331139.

36. Loesche, W. J., F. Gusberti, G. Mettraux, T. Higgins, and S. Syed. 1983. Relationship between oxygen tension and subgingival bacterial flora in untreated human periodontal pockets. Infect. Immun. 42:659-667.

37. Loesche, W. J. 1969. Oxygen sensitivities of various anaerobic bacteria. Appl. Microbiol. 18:723-727.

38. Lehrer, R. I., T. Ganz, D. Szklarek, and M. E. Selsted. 1988. Modulation of the in vitro candidacidal activity of human neutrophil defensins by target cell metabolism and divalent cations. J. Clin. Invest. 81:1829-1835.

39. Dewald, B., R. Rothild-Ludwig, U. Bretz, and M. Baggiolini. 1975. Subcellular localization and heterogeneity of neutral proteases in neutrophilic polymorphonuclear leukocytes. J. Exp. Med. 141:709-723.

40. Watorek, W., D. Farley, G. Salvesen, and J. Travis. 1988. Neutrophil elastase and cathepsin G: structure, function, and biological control. $A d v$. Exp. Med. Biol. 240:23-31.

41. Lehrer, R. I., K. M. Ladra, and R. B. Hake. 1975. Nonoxidative fungicidal mechanisms of mammalian granulocytes: demonstration of components with candidacidal activity in human, rabbit, and guinea pig leukocytes. Infect. Immun. 11:1226-1234.

42. Shafer, W. M., and S. A. Morse. 1987. Cleavage of protein III and major iron-regulated protein of Neisseria gonorrhoeae by lysosomal cathepsin G. $J$. Gen. Microbiol. 133:155-162.

43. Titani, K., T. Sasagawa, K. Resing, and K. A. Walsh. 1982. A simple and rapid purification of commercial trypsin and chymotrypsin by reversed-phase high-performance liquid chromatography. Anal. Biochem. 123:408-412. 